\title{
Coping With the Changes That Challenge Business and Education Sectors in Thailand $\mathbf{4 . 0}$
}

\author{
Kannapat Kankaew, College of Hospitality Industry Management, Suan Sunandha Rajabhat University, Thailand \\ (iD) https://orcid.org/0000-0003-1127-5627 \\ Ekachat Tansiri, Faculty of Liberal Arts and Science, Kasetsart University, Kamphaeng Saen, Thailand \\ Rojanard Waramontri, College of Hospitality Industry Management, Suan Sunandha Rajabhat University, Thailand \\ Nisara Paethrangsi, College of Hospitality Industry Management, Suan Sunandha Rajabhat University, Thailand \\ Korawin Kungwol, College of Hospitality Industry Management, Suan Sunandha Rajabhat University, Thailand \\ Bussaba Sitikarn, Mae Fah Luang University, Thailand \\ Kanittha Charernit, College of Hospitality Industry Management, Suan Sunandha Rajabhat University, Thailand
}

\begin{abstract}
This paper explores the ideas and cases based on research that emanate from the application of the contingency theory, resource-based views theory, and the institutional theory to cope with an abruptly changing paradigm. The paper attempts to provide a holistic view of the IR 4.0 impact on the business changes and the usage of technology in the education sector among Thais. This paper stresses the role of the educational sector by creating a shift from static into dynamic triggered by the intense competition in the Thailand markets. Keeping in view such a scenario, organizations should be pliable and enabled enough to transform existing resources into intellectual resources. This would result in the revitalization of the entire organizational human capital from leaders to teams and individuals contributing to morally support employee well-being, and this would reap extraordinary organizational results in terms of output. All this is seen through the lens of IR 4.0 as applied to the current Thai business and education scenario.
\end{abstract}

\section{KEYWORDS}

Business and Education, Challenges, Change Management, Contingency Theory, Human Resource Management, IR 4.0, Thailand 4.0

\section{INTRODUCTION}

The fourth industrial revolution, has come into existence in the past half a decade. It has been designated as Industry 4.0. The emphasis of industry 4.0 technologies is on the transformation in the means of using machines and obtaining information and analyzing data. The objective has been to foster highend production and promote faster and better goods manufacturing at considerably lower cost. The industrial revolution 4.0 is poised to benefit the economy through the growth of industries and the changed paradigm of changed working in various fields as also the emergence of numerous challenges. A Deloitte survey has reported a $70 \%$ spike in profit of businesses due to the implementation of the

\section{DOI: 10.4018/IJABIM.287588}

This article published as an Open Access article distributed under the terms of the Creative Commons Attribution License (http://creativecommons.org/licenses/by/4.0/) which permits unrestricted use, distribution, and production in any medium, provided the author of the original work and original publication source are properly credited. 
industry 4.0. As early as 2017 a survey had been conducted by Dhurakij Pundit University, showed that $59.66 \%$. Thais knew nothing of what was being popularized by the Thai government as 'Thailand 4.0'. The government is hosting the 'Thailand 4.0' agenda as an economic model based according to (Bussi \& Khatiwada, 2017), on:

(i) Creativity

(ii) Innovation

(iii) New technology

(iv) High-quality services

Thailand 4.0 is focusing on development through agriculture enhancing having been farmer oriented to favour mechanization and increased agricultural yield. It will also focus on light industry and utilize cheap labour for turning raw materials into finished goods like textiles and garments through production and manufacturing. The third component is advanced industry which is derived from the assembly and production of computer disk drives, electrical components, compressors, and automobiles for export (Rojniruttikul \& Rodchom, 2014). The mission of Thailand 4.0 is focused on making Thailand's labor force into 'knowledge workers' (Thailand Investment Review, 2017; Thailand's 20-Year National Strategy and Thailand 4.0 Policy, 2016).

\section{HISTORICAL PERSPECTIVE ON INDUSTRIAL REVOLUTIONS}

According to Alaloul et al (2020), "Ever since the industrialization era began in the 1700s, each industrial revolution carried its own signiðcant role in the advancement of today's development.

(i) In 1700s, mechanical looms were ðrst introduced which were driven by the power of water and steam on mechanical equipment and replaced the agricultural sectors, further enhancing the economic structure.

(ii) The Second Indus-trial Revolution occurred in 1870s, where electrical energy was introduced which formed a major system known as mass production. These revolutions relied on the number of human capabilities to achieve more.

(iii) The Third Industrial Revolution in 1970s occurred with the rise of electronics. The innovation of technology from analogue electronic and mechanical devices to today's digital technology available is referred to as Digital Revolution.

(iv) The Fourth Industrial Revolution (IR 4.0) is built upon the Digital Revolution where technology".

\section{SALIENT FEATURES OF IR 4.0}

The fourth phase of the industrial revolution, is based on the ongoing modification and upgradation of the conventional manufacturing and industrial practices obtaining buoyancy with the presentday smart technology. The industry 4.0 services, therefore, predominantly emphasize the extensive implementation of Machine-to-Machine communication, (M2M) and the Internet of Things or the IoT. Thus, IR 0.4 has focused on escalated automation, revamped communication, and self-monitoring through smart and intelligent machines or devices that can enable an efficient diagnosis of most industrial problems little or with no need for human presence to any great extent.

It was here in IR 4.0 that the primary phase of internet evolution was uplifted to the next level. With a vast range of internet extension with client and server models the gap between the physical and digital transformation vanished instantly. The primary technologies have given way to artificial intelligence, big data analysis and cloud computing which have today become public. These tech and internet inputs have ultimately resulted in making the automation processes more developed and 
optimized through different ways of using them. it can be acknowledged that the industry 4.0 revolution has brought out the best the industrial business worldwide. As the IR 4.0 is totally technology driven there are 9 Technologies that form its Salient drivers. These are detailed as follows:

(i) Big Data and Analytics: The storage and continued estimation of vast magnitudes of data besides producing gadgets and systems for customer management are problems facing the industry. These are being addressed in industry 4.0 as the leading real-time decision-making norms.

(ii) Simulation: Simulation techniques are used to grasp the data in real-time replicate the physical surroundings into virtual reality. It and eases the process of identifying machinery at threat virtually. This will affect quality positively.

(iii) Autonomous Robots: Robots will be used extensively in later years and work safely around humans.

(iv) Cybersecurity: To overcome threats due to connectivity of data on a large-scale cybersecurity comes into play. It follows the industry protocol and safeguards the information provided.

(v) Vertical and Horizontal System Integration: Industry 4.0 will promote universal data integrity and allow for the automation of the connected chains.

(vi) The Industrial Internet of Things (IIOT): The IoT in industry 4.0 has a big hand in allowing for faster decision making.

(vii) The Cloud Technology: Increased rate of production will require greater data sharing and therefore larger storing space, which has been provisioned for by the cloud.

\section{THAILAND 4.0: THE AWAKENING AND THE CHALLENGES}

The Fourth Industrial Revolution (IR 4.0) has been built upon Digital technology that has connected people across the globe. The ongoing technological breakthroughs are finding new ways of demonstrating the abilities and prowess of numerous physical, digital and biological entities (Davis 2018). This industry has focused majorly on sustainability as its foremost thrust (Hidayatno, Destyanto, Hulu 2019). Renewable energy and energy efficiency are the two focal components (Lemaire 2004). Renewable energy even currently contributes less than 25 percent consumption (Conti, Holtberg, Diefenderfer, LaRose, Turnure and Westfall 2016) where the energy efficiency has been facilitated greatly and has been influenced by technological innovations in the industrial sector (Nagasawa, Pillay, Beier, Fritzsche, Pougel, and Takama et al. 2017 and Alaloul, Hasaniyah, Tayeh 2017). The implementation, however, has not been easy (Upadhyaya S. Country grouping in UNIDO statistics 2013).

The IR 4.0 focal theme is viable and sustainable manufacturing systems (Carvalho, Chaim, Cazarini and Gerolamo 2018). The processes is having higher levels of the complexity no doubt but they smoothen the integrated production and products' processes all the while progressing towards a functional, productive, efficient yet sustainable system. All the three dimensions of sustainability, namely, social, economic and environmental carry the values of creation of sustainable industry by using industry 4.0 (Stock, Seliger G. 2016). The rising trends of digitization, automation and the wider use of Information and Communications Technology (ICT) in the industry contain technologies of cyber-physical systems, Internet of Things (IoT), cloud computing and cognitive computing which have been described as IR 4.0 and are the mandate for the road map of Thailand's dynamic progress and development. The concept of IR 4.0 is to digitize industrial processes to accomplish an adaptive yet extensive production and service network. The areas of facilitation as well as the opportunities present by the policy mandated by the Thai government can be seen in Table 1 which delineates the offerings of IR 4.0.

The Thai government policy has emphasized technology and innovation inputs as tools for boosting quality of life and improving economy simultaneously. 
Table 1. Some significant opportunities of IR 4.0 in Thailand

\begin{tabular}{|l|l|l|l|}
\hline Sr. No. & Opportunity & Details & Factor \\
\hline 1 & $\begin{array}{l}\text { Competitiveness rises to a global scale through adoption } \\
\text { of global standards and promotion of cutting- edge } \\
\text { technologies. }\end{array}$ & $\begin{array}{l}\text { Competitiveness } \\
\text { for Global quality } \\
\text { Checks }\end{array}$ & Political will \\
\hline 2 & $\begin{array}{l}\text { Innovative technologies and concepts decrease both } \\
\text { construction and product delivery time. The technologies } \\
\text { would also reduce costs such as labor and material cost }\end{array}$ & $\begin{array}{l}\text { Demand and } \\
\text { supply mechanisms } \\
\text { enhancement }\end{array}$ & $\begin{array}{l}\text { Growth of } \\
\text { Economy }\end{array}$ \\
\hline 3 & $\begin{array}{l}\text { The digital revolution of the industry would promote a more } \\
\text { innovative working environment rather than the conventional } \\
\text { conditions while improving partner collaborations and also } \\
\text { customer relationships }\end{array}$ & $\begin{array}{l}\text { Enhancement of } \\
\text { Tradition based } \\
\text { modern structures of } \\
\text { Functioning }\end{array}$ & Rubric of Society \\
\hline 4 & $\begin{array}{l}\text { The systems ensure error force quality assurance to promote } \\
\text { reliable decision-making based on informed choices } \\
\text { availability. }\end{array}$ & $\begin{array}{l}\text { Productivity } \\
\text { Parameters }\end{array}$ & $\begin{array}{l}\text { Technological } \\
\text { Inputs }\end{array}$ \\
\hline 5 & $\begin{array}{l}\text { Execution of a multi-pronged approach by using } \\
\text { technologies for reducing energy consumptions successively. } \\
\text { The waste generation is monitored, checked and prevented to } \\
\text { ensure a pollution free environment }\end{array}$ & $\begin{array}{l}\text { Promotes } \\
\text { Sustainability }\end{array}$ & $\begin{array}{l}\text { Environmental } \\
\text { Sustenance and } \\
\text { Conservation }\end{array}$ \\
\hline 7 & $\begin{array}{l}\text { Widespread implementation calls for establishment of } \\
\text { regulatory safeguards for reducing risk and uncertainties } \\
\text { mitigation of risks }\end{array}$ & $\begin{array}{l}\text { Framework of } \\
\text { safeguards }\end{array}$ & $\begin{array}{l}\text { Legislative and } \\
\text { Legal Frameworks }\end{array}$ \\
\hline
\end{tabular}

Source: Compiled by author kunnapat.ka@ssru.ac.th

Figure 1. The top to bottom Thailand 4.0 approach to development

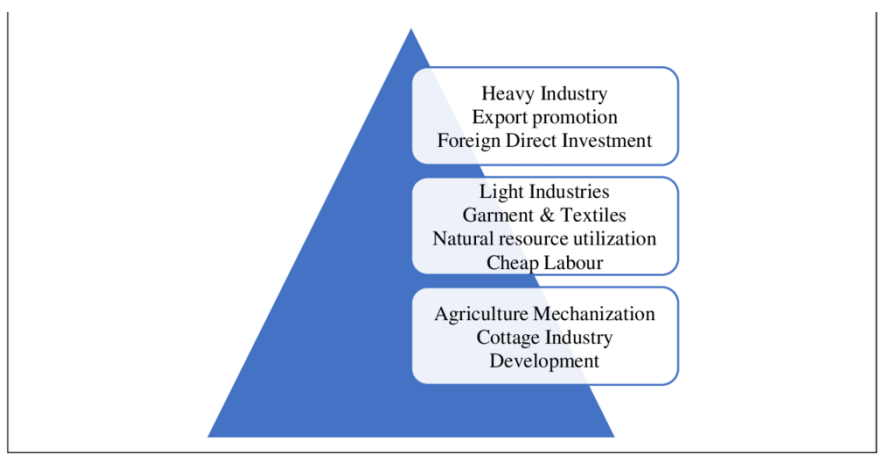

Source: Compiled by Author kunnapat.ka@ssru.ac.th

The Prime Minister of Thailand (2017) had outlined the usage of science, technology and innovation to boost the country's economy with special emphasis on focusing on industrial and agricultural sectors, medical technology and public health, as also the global trend setter, the robotics industry (Wipatayotin, 2017). The challenges to the adaption of Thailand 4.0 approach have been depicted in Table 2 that highlights the difficulties likely to be obstacles in Thailand's rapid paced movement towards development.

The Thai Embassy web site at Washington, D.C., delineates Thailand 4.0 optimized focal sectors for Foreign Direct Investment. These have been depicted in Figure 2. 


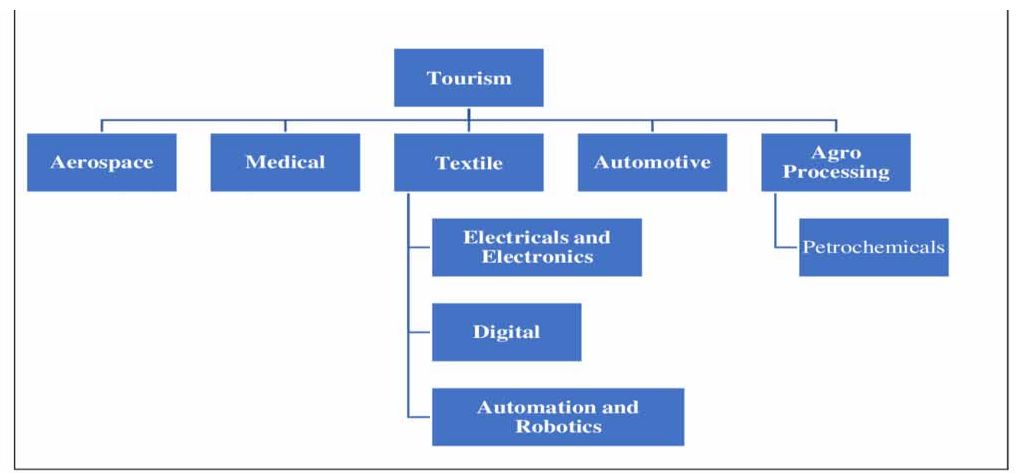

Source: Compiled by Author kunnapat.ka@ssru.ac.th

The "New Growth Engines" proposed under the Thailand 4.0 approach are:

(i) The "competitive growth engine" to free the larger proportion of the country from the middleincome trap.

(ii) The "moving forward together without leaving anyone behind growth engine" to eliminate the inequality trap.

(iii) The Green' growth engine that liquidates the environmental imbalance trap.

The dynamic changes in technology have been advancing continuously and unceasingly with elements of unpredictability. Furthermore, the quickly flow of data is resulting in firms taking competitive advantage from turning data into information that responded to the needs of customers through innovative products and services (Martins et al, 2019; Barao et al, 2017).

\section{COVID 19 PANDEMIC IMPACT: SOCIAL DISTANCING CANCELLED BY SOCIAL MEDIA MARKET PRESENCE}

The pandemic of COVID 19 encouraged faster external environment changes. The social distancing embellished the use of technology in daily life. A large number of applications have been introduced to facilitate businesses and economic endeavours. Multiple small businesses, restaurants, e-commerce trading units have emerged on the social media by pooling efforts with mobile application. These exchange activities have resulted in faster monetary flow in the system by a single lock-in and pay facilitation. For example, the Starbucks coffee outlet at Pearl Bangkok branch accepts only QR code payment in order to prevent employees touch bank notes and coins. Personally, another good point is that the money is directly transferred to the company account which is accurate and time saving. This eliminates several steps of human interface and promotes cashless purchases. The company can immediately evaluate the sales, most favored menus items, productivity, and consumer behavior. In the meantime, the money flows into the economic system faster. It is simply facilitated by just a few clicks and is free of charge. Even in the fresh market experienced the change as Post today (2020 December 12) reported that the fresh market called 'Ying Chareon' will create a cashless society through cooperate banks, and e-wallet companies and will encourage merchants and customers to use the QR code payment instead of cash. The market owner disclosed that the emergence of a cashless society will result in at least 6 safety benefits, namely,

(i) No risk of germs, 
Table 2. Emerging challenging of IR 4.0 in Thailand

\begin{tabular}{|c|c|c|c|}
\hline Sr. No. & $\begin{array}{l}\text { Explanation of Obstacles of } \\
\text { Manpower and Mindset }\end{array}$ & Detailed Action Points & Factors Affected \\
\hline 1 & $\begin{array}{l}\text { Companies have restricted their ability to } \\
\text { invest in technologies as they are currently } \\
\text { unclear of the benefits. The reliance on } \\
\text { governing bodies and authorities is optimum. } \\
\text { Their support provides an opportunity that } \\
\text { is essential for the implementation processes } \\
\text { especially through funding programs and a } \\
\text { number of collaborative partnerships. }\end{array}$ & Governance from top to down & Political will \\
\hline 2 & $\begin{array}{l}\text { Implementation of innovative technology } \\
\text { can be cost prohibitive. When return on } \\
\text { investment is not known is worse. Training } \\
\text { and equipment maintenance expenses are } \\
\text { long term which make implementation even } \\
\text { more difficult. The opportunity here reduces } \\
\text { costs significantly. }\end{array}$ & Financial Transparency in all fiscal mechanisms & Measurable economic gains \\
\hline 3 & $\begin{array}{l}\text { There is a widespread ripple effect } \\
\text { throughout all the processes involving } \\
\text { multiple parties. Therefore, the opportunity } \\
\text { here is to bring everybody on the same } \\
\text { platform. }\end{array}$ & Culture imbedded traditions and practices & Impact on social networks \\
\hline 4 & $\begin{array}{l}\text { Standard operating measures and processes } \\
\text { need to be redefined and enhanced. Enhanced } \\
\text { and improved equipment and skills operate } \\
\text { newer technologies to simplify. }\end{array}$ & $\begin{array}{l}\text { Challenges of transmission of Technology to grassroots to } \\
\text { level }\end{array}$ & Technological upgrades \\
\hline 5 & $\begin{array}{l}\text { All organizational processes be they } \\
\text { horizontal, vertical or end-to-end execution } \\
\text { processes have the absolutely essential need } \\
\text { to be redesigned for successful adaptation to } \\
\text { the changed and enhanced growth avenues } \\
\text { that are emerging and providing opportunities } \\
\text { for improvement. }\end{array}$ & $\begin{array}{l}\text { Processes and procedures of Organizational structure and } \\
\text { function }\end{array}$ & $\begin{array}{l}\text { Foremost concerns for } \\
\text { Environment }\end{array}$ \\
\hline 6 & $\begin{array}{l}\text { Responsibilities of stakeholders nurtured by } \\
\text { legal shortcomings add to complexity. These } \\
\text { can be eliminated totally. }\end{array}$ & Regulations to be put in place & $\begin{array}{l}\text { Legislative Safeguards and } \\
\text { Legal Provisions }\end{array}$ \\
\hline 7 & $\begin{array}{l}\text { Information exchange is placed under high- } \\
\text { risk situations. This creates opportunities for } \\
\text { multiple IT security processes to ensure data } \\
\text { privacy and data protection. }\end{array}$ & Risks calculated and unknown & $\begin{array}{l}\text { Safety and Security } \\
\text { mechanisms }\end{array}$ \\
\hline
\end{tabular}

Source: Compiled by Author kunnapat.ka@ssru.ac.th

(ii) No counterfeit money

(iii) No worries about carrying change

(iv) No risk of theft or money lost

(v) No fraudulent deals

(vi) No cheating of innocent ignorant persons like children elderly or tourists.

The rise of technology has brought about a shift in Thai consumer behavior. According to a survey of the National Statistical Office of Thailand (NSO) in March 2020 there were 68.4 percent of the Thai population that used high speed internet five to seven days a week. The tool most used to navigate the net is smartphone which accounted for 85.2 percent of the users. Thais found that the most useful of internet applications are the online shopping apps which accounted for 61.5 percent, followed by monetary services which were 42.8 percent, also medical services were 37.6 percent. Those who were checking information of the utilities' usage were 19.4 percent, while 16.3 percent were for agribusiness.

The Revenue Department of Thailand has estimated through data analytic methods that around six million online merchants existed including Youtube, Influencers etc. It has been announced that 
there would be implementation of a law to be implemented for collecting taxes as revenue from all e-commerce activities effective from 2021(Prachachat, 15 November 2020).

\section{THE COVID 19 PANDEMIC IMPACT ON HIGHER EDUCATION}

During the COVID 19 pandemic lockdown technological enhancement of the e-commerce marketplace allowed employees to work from home in a bid to protect everybody from the infectious disease. This did not, however, augur well for human resource planning, performance management, team and organization engagement. No doubt the educational sector extensively used numerous massive open online courses (MOOC) linked with credit bank system and the expertise of search engine like Google provided training courses with certificates in shorter learning span the life coaches, mentors, were geared to supply useful ideas through the social media where people shared their thought, activities and life experiences. Kankaew (2019) suggested that the information technology today relies on data that flows with velocity, volume, and variety.

The Office of the Higher Education Commission reveals that there are 155 higher education institutions including 83 public universities and 72 private universities. In 2019, the public universities announced admission of new intake 3.05 hundred thousand students (Thaipost, 2019 December 02). This is despite the fact that there are 3.7 hundred thousand students in the market waiting for entrance. Prachachart (2019) reported on the private universities that competed aggressively to grasp all the available students. To stay in the competition and remain viable the private universities reduced tuition fee by 40 to 50 percent. Several attractive features were also announced like scholarships, monetary support for life expenses, special discounts for groups and these joining with peers, suspensions of need for GAT-PAT, O-NET scores and portfolio, dormitory expenses waivers, provision of part-time jobs, provision of blended learning with fast-track online routes that allow students to graduate faster. This challenges all the previous operations in universities and higher education. Industrial revolution 4.0 (IR 4.0) has affected the educational sector in Thailand. The fourth industrial revolution has shifted the Thai society to supplementing information and knowledge economies (Panth \& Maclean, 2020).

\section{PARADIGM SHIFT TO FACE CHALLENGES OF THAILAND 4.0}

According to the National Statistical Office (NSO) of Thailand (2018, April 10) Thailand has been becoming an aged society since 2005, and has become a completely aged society in 2021. In 2031 the Thai society will be a super aged society. Many institutions have reviewed their programs seeing the increased age gradient.

The author's university has called the mechanisms of changes and phased them out as:

(i) Close

(ii) Change

(iii) Correct

Here the 'Close' refers to programs not interesting for the new intake students and having a small number of applicants. 'Change' refers to transforming programs by either combining departments or faculty and providing related program. Here 'Correct' refers to the changing of curriculum to serve the needs of stakeholders and students, amendment and modernizing of the curriculum. For this the department head shall invite concerned stakeholders to review and conduct the critical analysis of subjects, content, method of learning, skills and knowledge development. This is akin to the view of institutional theory highlights on the isomorphism the where organization has no choice behavior to adapt strategy for its legitimacy and survive in the competition (Lorsuwannarat, 2013). Hence, the university as institution with various expertise areas should demonstrate its professionalism both from 
within and outside. It should cooperate with other institutions. More than that, as the University as a higher education institution produces vital human capital for the country should lead the changes and expand the knowledge levels throughout.

\section{CONCLUSIONS AND RECOMMENDATIONS}

For implementing the processes of change leadership is vital for a resilient organization where the digitalized mindset aligns with contemporaneous need-based strategies. The new era of leadership should be combined through transformational and digitalized styles. Wherein Kankaew \& Trerattanaset (2020) felt that leaders should be agile and alert to adapt to the changed scenario with a digitalizedmindset, connected networks and analytically oriented direction. Thailand 4.0 faces the challenging manifestations of the population like quality of education, aging society, social structure and the impacted cultures and values. More importantly, distilling the data value, analyzing rivalries, and creating new strategies by equilibrating both human resource management and technology are essential. It is the responsibility of organizations to arm employees with technology tools, digital knowledge, and moral support through their confrontation with the pandemic. Considering that all the changes must be communicated and implemented throughout the organizations quickly the onus of responsibility falls on the HR professionals to understand the business context and coordinate with line managers. According to Ulrich et al (2012) six HR competencies should be highlighted, namely, change champions, strategic positioners, credible activists, capabilities builders, human resource innovators and integrators as well as technology proponents. The educational sector has virtually been a static organization where as currently the students are currently intensively competing in a dynamic world. This are the challenges that the 4.0 enabled Thailand has to rise to through he combined and concentrated efforts of its population. 


\section{REFERENCES}

Alaloul, W. S., Hasaniyah, M. W., \& Tayeh, B. A. A comprehensive review of disputes prevention and resolution in construction projects. MATEC web of conferences. doi:10.1051/matecconf/201927005012

Bakhshi, . (2017). The Future of Skills Employment in 2030. Pearson.

Barney, B. J., \& Clark, N. D. (2009). Resource-Based Theory: Creating and Sustaining Competitive Advantages. Oxford University Press.

Becker, B. E., \& Huselid, M. A. (2006). Strategic Human Resources Management: Where Do We Go From Here? Journal of Management, 32(6), 898-925. doi:10.1177/0149206306293668

Bohlouli, , Mittas, N., Kakarontzas, G., Theodosiou, T., Angelis, L., \& Fathi, M. (2017). Competence Assessment as an Expert System for Human Resource Management: A Mathematical Approach. Expert Systems with Applications, 70, 83-102. doi:10.1016/j.eswa.2016.10.046

Bussi, M., \& Khatiwada, S. (2017, April 11). Thailand 4.0 and the future of work. Bangkok Post. Retrieved from http://tinyurl.com/y86afunj

Carvalho, N., Chaim, O., Cazarini, E., \& Gerolamo, M. (2018). Manufacturing in the fourth industrial revolution: A positive prospect in Sustainable Manufacturing. Procedia Manufacturing, 21, 671-678. doi:10.1016/j. promfg.2018.02.170

Charlie, J., \& Paitoon, P. (2017). Innovative ideas: Thailand 4.0 and the Fourth Industrial Revolution. Asian International Journal of Social Sciences, 17(1), 4-32. doi:10.29139/aijss.20170101

Conklin, W. (2013). Higher-Order Thinking Skills to Develop $21^{\text {st }}$ Century Learners. Shell Educational Publishing.

Conti, J., Holtberg, P., Diefenderfer, J., LaRose, A., Turnure, J. T., \& Westfall, L. (2016). International energy outlook 2016 with projections to 2040. Washington, DC: US DOE Energy Information Administration (EIA).

Davenport, H. T., \& Harris, G. J. (2017). Competing on Analytics: The New Science of Winning. Harvard Business Review Press.

Davis, N. (2018). What is the fourth industrial revolution? Retrieved from https://www.weforum.org/ agenda/2016/01/what-is-the-fourth-industrial-revolution

Dawson, P. (2003). Understanding Organizational Change: The Contemporary Experience of People at Work. SAGE.

Donalson, L. (2001). The Contingency Theory of Organization. Sage (Atlanta, Ga.).

Hecklau, F., Galeitzke, M., Flachs, S., \& Kohl, H. (2016). Holistic Approach for Human Resource Management in Industry 4.0. Procedia CIRP, 54, 1-6. doi:10.1016/j.procir.2016.05.102

Hidayatno, A., Destyanto, A. R., \& Hulu, C. A. (2019). Industry 4.0 technology implementation impact to industrial sustainable energy in Indonesia: A model conceptualization. Energy Procedia, 156, $227-233$. doi:10.1016/j.egypro.2018.11.133

Islami, X., Mulolli, E., \& Mustafa, N. (2018). Using Management by Objectives as a Performance Appraisal Tool for Employee Satisfaction. Future Business Journal, 4(1), 94-108. doi:10.1016/j.fbj.2018.01.001

Kagermann, H., Wahlster, W., Helbig, J. (2013). Umsetzungsempfehlungen für das Zukunftsprojekt Industrie. Secure the future of Germany as a production location, implementation recommendations for the future project industry 4.0. Secretariat of the Platform Industrie 4.0.

Kankaew, K. (2019). Is Human Capital in Higher Education Ready for Thailand 4.0: A Case Study of SSRUIC Students, Nakorn Pathom Education Center. Journal of Educational and Social Research, 9(3), $203-210$. doi:10.2478/jesr-2019-0038

Kankaew, K., \& Trerattanaset, P. (2020). The Organization Culture Affecting Job Performance of Newly Hired Employees: A Case Study of the Customs Bureau at Bangkok Suvarnabhumi International Airport, Thailand. In A. Bejaoui (Ed.), Corporate Leadership and Its Role in Shaping Organizational Culture and Performance (pp. 129-155). IGI Global. 
Kannapat, K., Kanittha, C., Rojanart, W., Korawin, K., \& Theppaluck, K. (2020). Learning Organization: The Challenges of Knowledge Management in the Changing Paradigm. Journal of Legal Entity Management and Local Innovation, 6(2), 241-254.

Kitapci, H., \& Celik, V. (2013). Ambidexterity and Firm Productivity Performance: The Mediating Effect of Organizational Learning Capacity. Social and Behavioral Sciences, 99, 1105-1113. doi:10.1016/j. sbspro.2013.10.584

Lemaire, X. (2004). Glossary of terms in sustainable energy regulation. Renewable Energy and Efficiency Partnership. Centre for Management under Regulation, Warwick Business School, University of Warwick.

Lorsuwannarat, T. (2013). Organization Theory: Multi-Paradigm Perspectives. Bangkok: DKprintingworld.

Mweru, C. M., \& Muya, T. M. (2016). Features of Resources Based View Theory: An Effective Strategy in Outsourcing. International Journal of Management and Commerce Innovations, 3(2), 215-218.

Nagasawa, T., Pillay, C., Beier, G., Fritzsche, K., Pougel, F., Takama, T., The, K., \& Bobashev, I. (2017). Accelerating clean energy through Industry 4.0: Manufacturing the next revolution. A report of the United Nations Industrial Development Organization.

National Statistical Office. (2018, April 10). What statistic tells the elderly now and future? Retrieved from http://www.nso.go.th

Panth, B., \& Maclean, R. (2020). Introductory Overview: Anticipating and Preparing for Emerging Skills and Jobs-Issues, Concerns, and Prospects. In B. Panth \& R. Maclean (Eds.), Anticipating and Preparing for Emerging Skills and Jobs. SAGE. doi:10.1007/978-981-15-7018-6_1

Pipat. (2016, July 22). Disruptive Technology and Investment. Thaipublica. Retrieved from www.thaipublica.org PMAT. (2020, December 9). Building Organizational Resilience. Retrieved from https://www.facebook.com/ pmatHRsociety

Pokpong, C., \& Supanat, S. (2013). Human Capital Development for Better Productivity. Paper presented at the New Development Model: Towards Quality Growth Based on Productivity Improvement.

Posttoday. (2020, December 12). Ying Chareon Market Apply Cashless Society for New Normal. Retrieved from https://www.posttoday.com/economy/news/640092

Prachachat. (2019, June 6). Aggressive Competition of Private Universities Could Lead to Bankruptcy. Retrieved from https://www.prachachat.net

Prachachat. (2020, November 15). Revenue Department Preparing to Collect Taxes from E-Commerce. Retrieved from https://www.prachachat.net/finance/news-556183

PwC. (2019). It's Time for a Consumer-Centered Metric: Introducing Return on Experience. Retrieved from https://www.pwc.com

Rojniruttikul, N., \& Rodchom, P. (2014). Thai hard-disk drive industry knowledge management: The application of failure mode and effect analysis. Asian International Journal of Social Sciences, 14(2), 77-83. doi:10.29139/ aijss.20140205

Stock, T., \& Seliger, G. (2016). Opportunities of sustainable manufacturing in industry 4.0. Procedia CIRP, 40, 536-554. doi:10.1016/j.procir.2016.01.129

Thailand Investment Review. (2017). Thailand 4.0 mean opportunity Thailand. Retrieved from http://tinyurl. $\mathrm{com} / \mathrm{m} 4 \mathrm{gxq} 47$

Thaipost. (2019, December 2). TCAS 63 New Students Intake 3.05 Hundred Thousand from 81 Universities. Retrieved from https://www.thaipost.net/main/detail/51604

The Nation. (2016, March 7). Thailand pushes for next-generation automotive. Retrieved from http://tinyurl. com/mgq9zkx

Ulrich, . (2012). HR from the Outside in. McGraw-Hill.

Upadhyaya, S. (2013). Country grouping in UNIDO statistics (Vol. 1). Academic Press. 
Werner, J. M., \& DeSimone, R. L. (2009). Human Resource Development. Cengage.

Wesam, S. A., Liew, M. S., Noor, A. W., Abdullah, Z., \& Ickx, B. K. (2020). Civil Engineering Industrial Revolution 4.0 in the construction industry: Challenges and opportunities for stakeholders. Ain Shams Engineering Journal, 225-230.

Wipatayotin, A. (2017, March 18). Prayut touts 'Thailand 4.0' for farmers. Great chance to boost life quality, PM says. Bangkok Post. Retrieved from http://tinyurl.com/ldzkmvz

Wirtz, J., \& Lovelock, C. (2016). Services Marketing (8th ed.). World Scientific. doi:10.1142/y0001

Witoorut, P. (2020). Necessary Skills in 2020. Retrieved from https://:www.thematter.co/ 